\title{
Supply chain performance measurement in the automotive sector: A structured content analysis
}

\author{
Radouane Lemghari $^{a^{*}}$, Driss Sarsria ${ }^{a}$, Chafik Okar ${ }^{\mathrm{b}}$ and Asmaa Es-satty
}

${ }^{a}$ National School of Applied Sciences of Tangier, Abdelmalek Essaâdi University, Tangier, Morocco

${ }^{b}$ National School of Applied Sciences of Berrechid, Hassan the 1st University, Settat, Morocco

\section{H R O N I C L E}

\begin{tabular}{l}
\hline Article history: \\
Received May 5, 2019 \\
Received in revised format May \\
20,2019 \\
Accepted June 22019 \\
Available online \\
June 2 2019 \\
\hline Keywords: \\
Supply chain \\
Performance measurement \\
Automotive sector \\
\end{tabular}

\section{A B S T R A C T}

\begin{abstract}
This study, both descriptive and exploratory, aims to examine the scientific literature on the supply chain performance measurement (SCPM) in the automotive sector over the last 12 years. The analysis featured 30 articles corresponding to the research topic of the Scopus database. The most pertinent articles, authors, keywords, countries, research laboratories and journals are presented using the analysis of bibliographies on the subject from 2007 to 2018 in the Industrial Engineering domain. The conclusion is performed by the systematic analysis that the automotive sector is well controlled on the subject of performance. The selected studies show that lack of understanding of the performance measurement system (PMS) and lack of management dedication are the main obstacles. Finally, various guidelines are provided to optimize the supply chain in the automotive sector.
\end{abstract}

(C) 2019 by the authors; licensee Growing Science, Canada.

\section{Introduction}

Supply chain management (SCM) goes beyond logistics when integrating of business operations and the key process administration in the value chain from the product development to the marketing. Thus, it can be said that SCM is multifunctional and involves areas of production management, marketing, purchasing and logistics (Neto \& Pires, 2012). Due to this structure complexity, the performance of the supply chain remains as one of the most critical issues in the supply chain. It is emphasized that measuring the supply chain performance is essential for an effective management of the supply chain (Dörnhöfer \& Günthner, 2017). Otherwise, it is argued that measuring the global supply chain performance is necessary. On one hand, it ensures an efficient SCM for the company. Becoming a fundamental management tool, performance measurement allows managers to successfully manage the supply chain efficiently and effectively, i.e. it gives the support needed for performance enhancement as a means to achieve supply chain excellence (Bolstorff \& Rosenbaum, 2011).

Over the past two decades, several frameworks and systems have been deployed to reach strategic directions (Dörnhöfer \& Günthner, 2017; Osati \& Omidvari, 2016). In fact; integrating performance measurement within a company helps to assess overall performance across the supply chain and identify the internal improvement actions that have to be persuaded in order to make a better significant impact on competitiveness (Croxton et al., 2001; Neto \& Pires, 2012). Throughout its history, the need

* Corresponding author

E-mail address: lemghari.radouane@gmail.com (R. Lemghari)

(C) 2019 by the authors; licensee Growing Science. doi: $10.5267 /$ j.uscm.2019.6.002 
to measure performance has amplified since the creation and growth of large companies. In other words, the measurement mechanisms and the evaluation process were integrated into the business atmosphere since the start of series production. The primary kind of measurement system established was made by Taylor in the development of work rationalization (Brandão \& Guimarães, 2001). This period was the start of the implementation of the performance measurement in companies (Neto \& Pires, 2012).

In the same context, Eccles (1991) emphasized that measurement systems must illustrate the situation of a company in relation to its current competitors and not to its own practice. However new requirements for performance measurement treat the cost, quality, and delay as mere elements of a set of expansive measures instead of the main measures (Carr \& Hasan, 2009). Performance measurement also helps managers to operate the source of productivity to achieve better organizational goals (Eswaramurthi \& Mohanram, 2013; Chahid et al., 2014). Performance measurement is one of the essential elements of management and performance systems derived from the results of decisions made by managers (Neely et al., 2000), furthermore, it is an important element of effective planning and control as well as decision making (Eskafi et al., 2015). As for the supply chain performance measures categories it is emphasized that it can be categorized into qualitative and quantitative measures. The qualitative measures are more difficult to measure than quantitative measures given their complexity and the subjectivity they require. Examples of qualitative measures are effective risk management and supplier performance, customer satisfaction, flexibility, and the integration of material and information flows. The qualified measures as quantitative are those related to costs and customer satisfaction (Beamon, 1998; Neto \& Pires, 2012).

From this context, this article aims to study the scientific literature on performance measurement (PM) in the automotive sector over the last 12 years, in order to identify how this sector deals with and minimizes its impacts on the supply chain while leading to an improvement of its products. The article contains six sections, the first embodies the introduction. The second presents an overview of the performance measurement within the automotive supply chain. The third develops the methodology used in this research. The fourth section presents the results. The fifth section presents the discussions. Finally, we present the conclusions.

\section{Performance measurement and Automotive Sector}

The automotive sector has a direct influence on the development of the country's economy and technology. It was emphasized that the automotive sector is global and is specified as a capital-intensive industry with vertical integration and economies of scale (Schulze et al., 2015). It has been responsible for the evolution of technological innovation and management, as well as for the important initial change in industrial production processes (Goldenstein \& Casotti, 2008; Oliveira et al., 2018). Since the mid-1980s, the automotive sector has gone through a period of transition during which domestic industries adapt to an integrated global market (Sturgeon et al., 2008). According to the authors, this integration was mainly in the buyer-supplier relationship, particularly between car manufacturers and their suppliers. In this context, this industry must provide world-class products as highly competitive market demands; and for its survival, it must be flexible, proactive, responsive and competitive cost. To evaluate its realization, manufacturers adopt continuous PM as the main drivers of performance (Rahman et al., 2010). However, over the years the industrial accounting has been founded on a cost accounting exercise that has failed to incorporate all the critical factors of successful manufacturing (Kennerley \& Neely, 2003; Chahid et al., 2014).

Based on its complex automotive components and technologies, the automotive sector itself intended to find more convenient approaches for improving and promoting supply chain performance. Although, it has faced some challenges such as on-time delivery, time to market, environmental issues, limitation of pricing, customer services, product quality, product lifecycle, new-product development product life cycle, product's costs and supplier collaboration. To cope with this variety of issues, the PM was embraced as a basic part of the performance SCM (Gholampour et al., 2015). It was mentioned by Sink and Tuttle that it is very difficult to manage what cannot be measured (Sink \& Tuttle, 1989), and similarly Kaplan and Norton (1992) stated: 'No measures, no improvement'. Which means that it is 
essential to measure the right thing at the right time in supply chains to enable timely decision-making and performance within the supply chain.

Performance measurement has its roots in double-entry accounting, which began at the end of the 13th century and remained unchanged until the industrial revolution of the early 19th century (Johnson et al., 1998). Moreover, performance measurement was used to monitor performance, identify processes that lead to performance gaps, increase motivation, improve communication, and strengthen accountability as demonstrated by several studies (Waggoner et al., 1999). In fact, the development of a SCPMS has different objectives, including determining success, understanding business processes, determining whether customer needs are being met, providing evidence-based decisions, monitoring progress and identifying bottlenecks, enabling progress, waste, problems and opportunities for improvement (Gunasekaran \& Kobu, 2007).

In addition, PM criteria should be founded on business objectives and have a clear definition of purpose and scope to concentrate on suitable data collection and calculation methods (Ptak \& Schragenheim, 2000). Historically, it has focused on cost, time and quantity, without considering the important dimensions of employee and client satisfaction, health and safety, environmental impact and sustainability. No one finds the right balance between simplicity and answers which are accurate enough (Horner, 2006; Lemghari et al., 2018b). The performance of manufacturing companies depends mainly on their production process, in their process of continuous improvement; The use of performance measurement has turned into a major area of research in industry and academia, as companies invest more human and material resources to measure their performance (Aracioğlu et al., 2013; Chahid, J. El Alami, et al., 2014). In addition, the rapid transformation and dramatic growth of the automotive industry have opened up a vast area of research involving the SCPM. The development of the link between car producers and their suppliers and practitioners is attended by a necessity to modify the systems for SCPM (Neto \& Pires, 2012).

In summary, there are many researches in the literature about performance measurement. However, in each study different properties of performance are evaluated. Indeed, our study focuses on the development of the PM literature in the period from 2007 and 2018, in order to explore how the supply chain performance measurement has been treated by academic researchers and practitioners, to identify what are the relevant approaches and frameworks that were suggested in the light of the performance measurement and to highlight its properties and objectives.

\section{Methods}

This research is described as theoretical. Considering its technical procedures; it corresponds to a bibliographic study, as we report data and verifications stemming directly from previous literature on the subject. The perspective's objectives are categorized as exploratory and descriptive since they look for specific information and characteristics of what is being studied. A structured content analysis of the literature, using bibliometric analysis, was conducted using the Constructivist of Knowledge Development (the ProKnow-C method) proposed by (Ensslin et al., 2014). The ProKnow-C intervention method suggested by (Ensslin et al., 2014) for selecting a bibliographic portfolio (Fig. 1) includes the following four-step processes:

- Selecting a raw material database, this includes: selecting keywords, selecting databases, searching for articles, and verifying keyword adherence;

- Filtering the raw material database, this involves filtering the raw database items by redundancy and filtering the raw database items that are not recurrent by the title alignment;

- Filtering of the article list, to determine scientific recognition of articles, author identification;

- Filtering by aligning articles covering the entire article with the full text. 


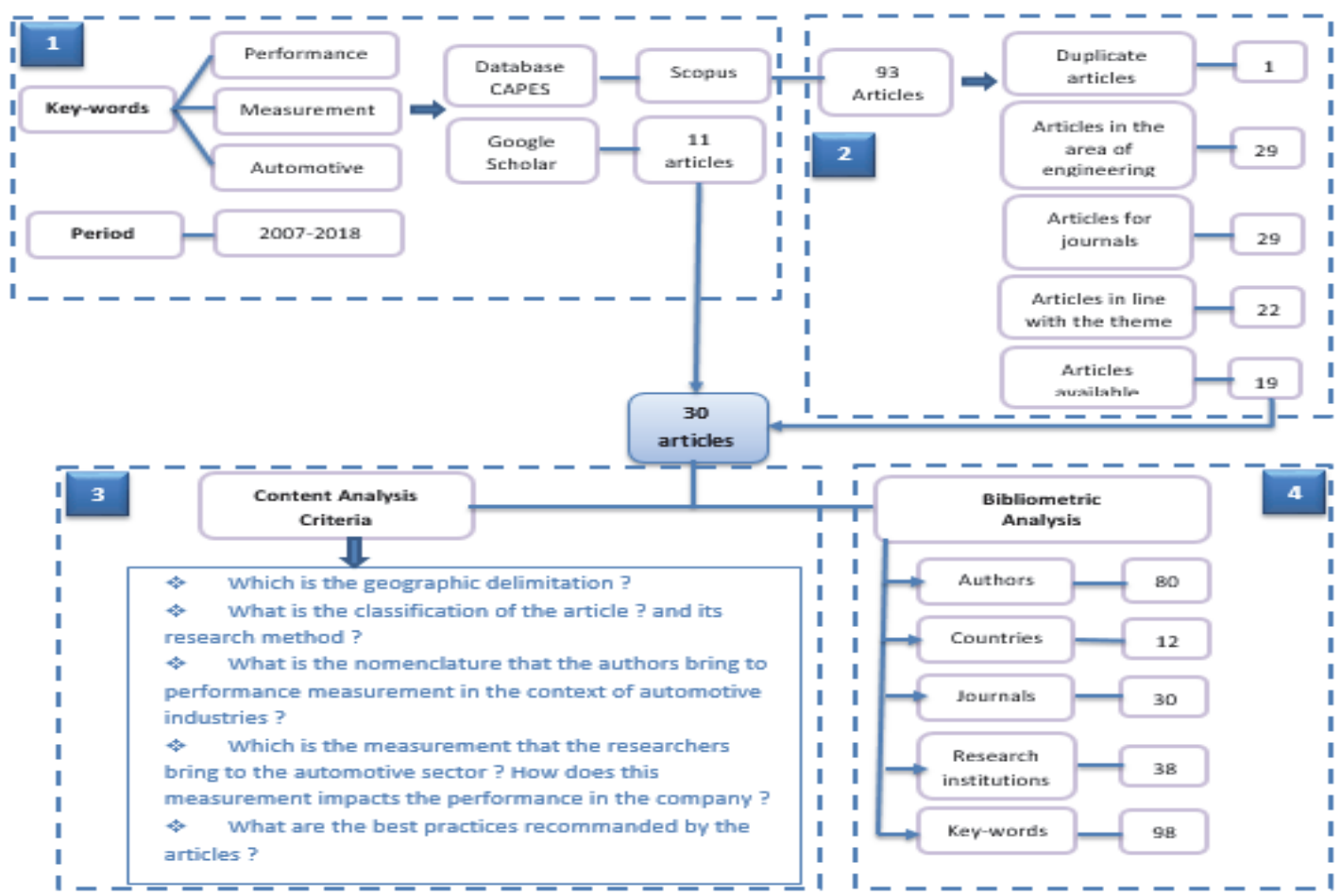

Fig. 1. Bibliographic portfolio.

First, we identified the keywords "Supply chain *", "performance measurement*" and "Automotive", in August 2018. We have chosen the Scopus database because it is multidisciplinary and only indexes the most frequently cited journals in their respective fields. It lists over 15,000 periodicals, approximately 265 million web pages, 18 million patents, among other documents (Vaz et al., 2017).

The search resulted in 93 articles associated with the topic in the last 12 years. These were divided by research fields: $32 \%$ stemmed from engineering, 13\% environmental science, $12 \%$ from Physics and Astronomy, $10 \%$ of computer science and $7 \%$ from materials science. Nevertheless, our study concentrated in the Engineering area, by the reason that it presents the superior amount of articles and that it is the research field of the authors, as illustrated in Fig. 2.

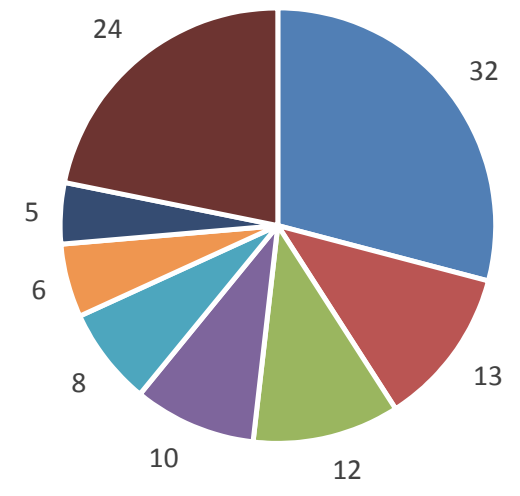

$\begin{array}{lll}\text { - Engineering } & \text { - Environmental Science } & \text { - Physics and Astoronomy }=\text { Computer Science } \\ \text { m Matrial Science } & \text { - Mathematics Energy }\end{array}$

Fig. 2. Areas of the articles found in the Scopus database 
The total of 93 articles went through consecutive filters until finding a more adherent result to the aims of our research. This filter has the purpose of rejecting undesirable articles and also of improving the research process, so no needless time is dedicated to the full-text reading of articles that do not add value for the purpose of our research. For the filtering method, some characteristics were considered:

- $\quad$ Existence of duplicates/duplicate articles (total of 1 article);

- $\quad$ Correspondence with the engineering field (29 articles);

- $\quad$ Articles published in journals (29 articles);

- $\quad$ Correspondence of the titles/abstracts of the articles with the theme (22 articles); and

- $\quad$ Accessibility of articles in full-text (19 articles).

At this phase, an exploratory search in Google Scholar was prepared with the keywords to add supplementary studies on the topic. 11 articles were selected that were not indexed in the SCOPUS database. Thus, 30 articles were defined to compose the bibliographic collection of our paper.

The list of the 30 articles aligned with the subject of "Supply chain AND performance measurement AND Automotive Sector" is presented in appendix A, which will be studied through bibliometric and content analysis, which will allow to select the main authors, journals and keywords on our topic studied. Indeed, these methods allow the use of statistical and mathematical techniques to map information from the bibliometric details of documents based on recognized scientific theoretical foundation as explained by Uriona and Maldonado Silva Santos (Vanalle \& Santos, 2014). However, the study of the content was established according to the criteria created by Bardin (Laurence Bardin, 2016). In addition, and as illustrated in Fig. 1, some criteria were created by the researchers to organize the analysis, code the data, categorize, create inferences, and correct research deficiencies on the subject of PM in the automotive sector. For this, two software were used for the management and the tabulation of collected data: Mendeley and VosViewer.

The first is Mendeley Software (Saleh, 2012) which was used to manage and process the collected references. Developed by Mendeley Ltd., Mendeley (http://www.mendeley.com) is a software that simplifies research and writing scientific work by gathering references and citations in online databases. The grouping of their metadata allows to make quantitative analyzes of authors, journals, keywords, research centers, etc. The second software used is VosViewer, which is utilized to build bibliometric networks from data downloaded from bibliographic platforms like Web of Science (WoS) and Scopus. Also, the possibility to choose between the use of the total and the fragmented counting method is allowed for the user (van Eck \& Waltman, 2010). Therefore, Vosviewer is used in this research to conduct a study of co-authors and co-occurrence of keywords (Vaz et al., 2017).

\section{Results}

The literature analysis allows researchers to become familiar with the subject. For this reason, it is always applied as the first step in the study, to cultivate and develop knowledge in a specified context (Afonso et al., 2012). Sharing with the reader the results of other studies directly related to what is done and / or studied is one of the most pertinent objectives of the literature analysis (Creswell, 2007) (Ensslin \& Ensslin, 2012). For our case, the 30 articles were published by 80 authors and coauthors. Over a 12-year period, they were published in 30 journals, with 745 references cited, 98 keywords produced by 12 countries (including the United States, Japan, France, India and The Netherlands) in 38 institutions/research centers (most notably Cardiff University and University of Delaware).

The chronological classification of the 30 articles is explained in Fig. 3. The first article published on this subject was in 2007 whose title was:

"Performance measurement of the after-sales service network: Evidence from the automotive industry", by Gaiardelli et al. (2007): This study shows that to ensure strategic coherence, the PMS of the different 
actors in the SC must be aligned. In fact, it offers an integrated background and a practical application for the PM of two automotive case companies.

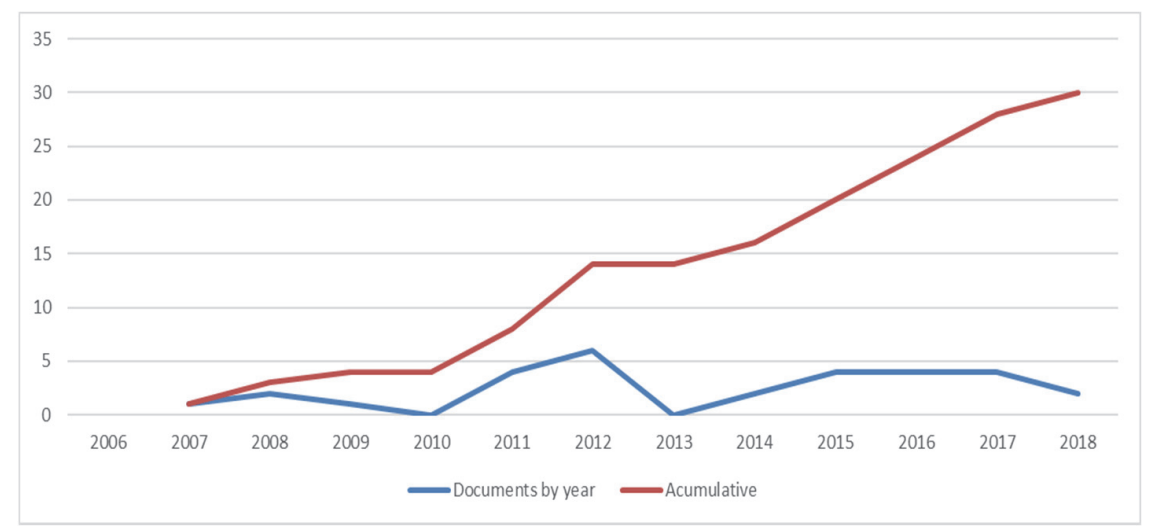

Fig. 3. Publications periodicity

We selected 80 authors and co-authors from the most pertinent authors in the 30 articles. The most prolific authors with two articles each were (Chahid et al., 2014; Charan et al., 2012; Dörnhöfer \& Günthner, 2016; Dörnhöfer et al., 2016 Dörnhöfer \& Günthner, 2017; Behrouzi \& Wong, 2011; Olugu and Wong, 2012).

The network of co-authors of 80 elements are grouped into 26 clusters with 98 links as presented in Fig. 4. We can conclude that the authors of our topic "performance measurement in the Automotive Sector" work in separation and with only a few partnerships.

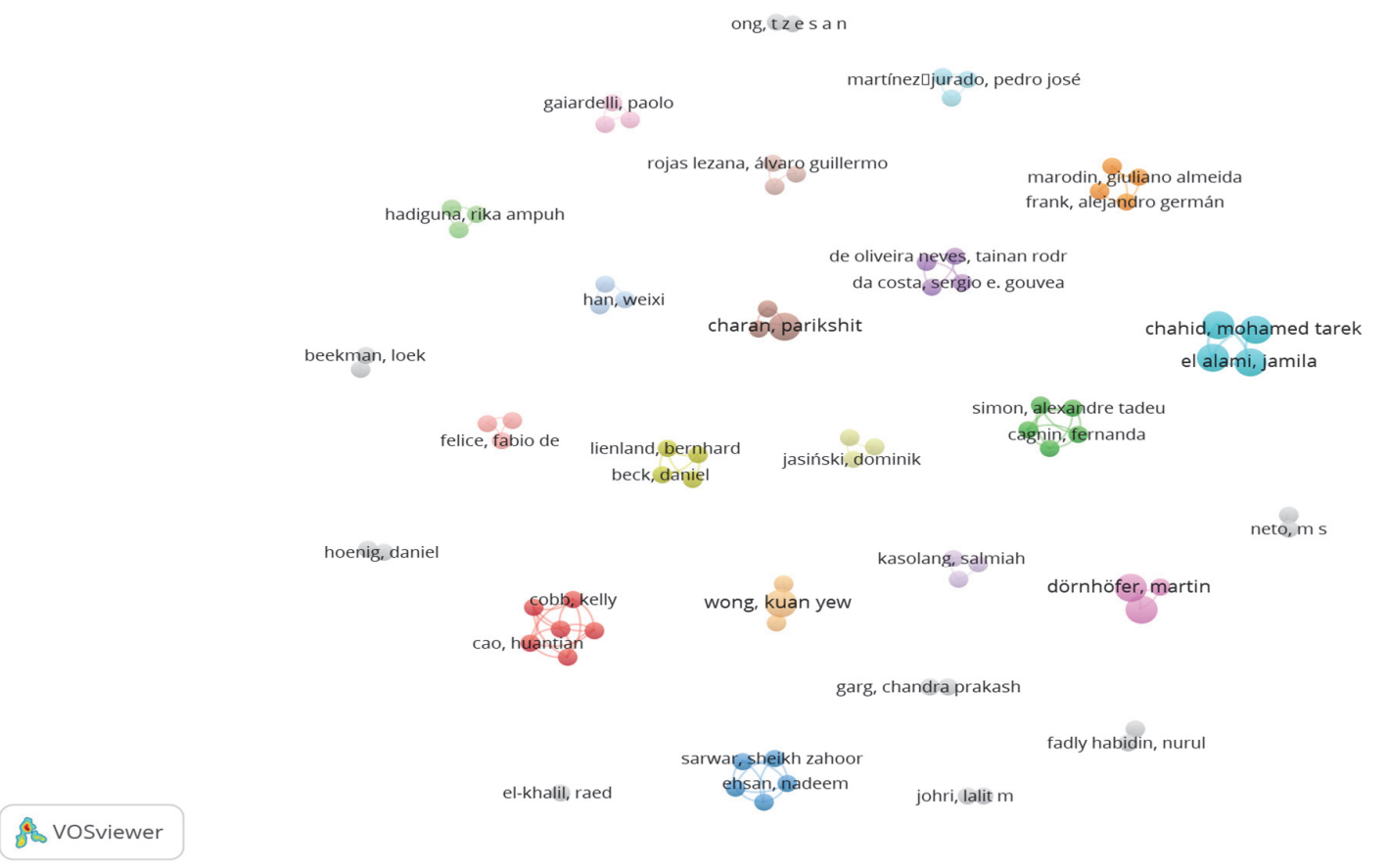

Fig. 4. Author Co-authorship clusters.

Furthermore, the largest clusters with more than 4 authors are red, green, yellow and blue (more details are exposed in Table 1). 
Table 1

Authors' information, Country and Research Institutions

\begin{tabular}{|c|c|c|c|c|}
\hline Clusters & Author & Research Institutions & Country & Research Area \\
\hline \multirow{6}{*}{ Red } & Huantian Cao & University of Delaware & USA & $\begin{array}{c}\text { Sustainability } \\
\text { Environmental performance } \\
\text { Protective clothing }\end{array}$ \\
\hline & Marsha A. Dickson & University of Delaware & USA & $\begin{array}{l}\text { Sustainability } \\
\text { Corporate Social Responsibility } \\
\text { Environmental performance }\end{array}$ \\
\hline & Kelly Cobb & University of Delaware & USA & $\begin{array}{c}\text { Sustainability } \\
\text { Environmental performance } \\
\text { Social responsibility }\end{array}$ \\
\hline & Martha Carper & University of Delaware & USA & $\begin{array}{c}\text { Sustainability } \\
\text { Environmental performance } \\
\text { Social responsibility }\end{array}$ \\
\hline & Crescent Scudder & University of Delaware & USA & $\begin{array}{c}\text { Sustainability } \\
\text { Social responsibility }\end{array}$ \\
\hline & Crispin Wong & University of Delaware & USA & $\begin{array}{c}\text { Sustainability } \\
\text { Environmental performance }\end{array}$ \\
\hline \multirow{5}{*}{ Green } & Fernanda Cagnin & $\begin{array}{l}\text { Methodist University of } \\
\text { Piracicaba }\end{array}$ & Brazil & $\begin{array}{c}\text { Risk management } \\
\text { Automotive industry } \\
\text { Quality }\end{array}$ \\
\hline & Maria Celia de Oliveira & $\begin{array}{l}\text { Methodist University of } \\
\text { Piracicaba }\end{array}$ & Brazil & $\begin{array}{l}\text { Risk management } \\
\text { Automotive industry } \\
\text { Quality }\end{array}$ \\
\hline & $\begin{array}{l}\text { Alexandre Tadeu } \\
\text { Simon }\end{array}$ & $\begin{array}{l}\text { Methodist University of } \\
\text { Piracicaba }\end{array}$ & Brazil & $\begin{array}{l}\text { Risk management } \\
\text { Automotive industry } \\
\text { Quality }\end{array}$ \\
\hline & André Luis Helleno & $\begin{array}{l}\text { Methodist University of } \\
\text { Piracicaba }\end{array}$ & Brazil & $\begin{array}{l}\text { Risk management } \\
\text { Automotive industry } \\
\text { Quality }\end{array}$ \\
\hline & $\begin{array}{l}\text { Matheus Phelipe } \\
\text { Vendramini }\end{array}$ & $\begin{array}{l}\text { Methodist University of } \\
\text { Piracicaba }\end{array}$ & Brazil & $\begin{array}{l}\text { Risk management } \\
\text { Automotive industry } \\
\text { Quality }\end{array}$ \\
\hline \multirow{5}{*}{ Blue } & Sheikh Zahoor Sarwar & $\begin{array}{l}\text { Center for Advanced Studies } \\
\text { in Engineering }\end{array}$ & Pakistan & $\begin{array}{l}\text { Productivity analysis } \\
\text { Manufacturing } \\
\text { Automotive industry }\end{array}$ \\
\hline & Azam Ishaque & $\begin{array}{l}\text { Center for Advanced Studies } \\
\text { in Engineering }\end{array}$ & Pakistan & $\begin{array}{l}\text { Productivity analysis } \\
\text { Manufacturing } \\
\text { Automotive industry }\end{array}$ \\
\hline & Nadeem Ehsan & $\begin{array}{c}\text { Center for Advanced Studies } \\
\text { in Engineering }\end{array}$ & Pakistan & $\begin{array}{l}\text { Productivity analysis } \\
\text { Manufacturing } \\
\text { Automotive industry }\end{array}$ \\
\hline & Danial Saeed Pirzada & $\begin{array}{c}\text { Center for Advanced Studies } \\
\text { in Engineering }\end{array}$ & Pakistan & $\begin{array}{l}\text { Productivity analysis } \\
\text { Manufacturing } \\
\text { Automotive industry }\end{array}$ \\
\hline & Zafar Moeen Nasir & $\begin{array}{c}\text { Pakistan Institute of } \\
\text { Development Economics }\end{array}$ & Pakistan & $\begin{array}{c}\text { Productivity analysis } \\
\text { Manufacturing } \\
\text { Automotive industry } \\
\end{array}$ \\
\hline \multirow{4}{*}{ Yellow } & $\begin{array}{l}\text { Mohamed Tarek } \\
\text { CHAHID }\end{array}$ & $\begin{array}{l}\text { University Mohammed V- } \\
\text { Agdal }\end{array}$ & Morocco & $\begin{array}{l}\text { Performance Measurement model } \\
\text { Moroccan automotive suppliers } \\
\text { Analytical Hierarchy Process }\end{array}$ \\
\hline & Jamila EL ALAMI & $\begin{array}{l}\text { University Mohammed V- } \\
\text { Agdal }\end{array}$ & Morocco & $\begin{array}{l}\text { Performance Measurement model } \\
\text { Moroccan automotive suppliers } \\
\text { Analytical Hierarchy Process }\end{array}$ \\
\hline & Aziz SOULHI & $\begin{array}{l}\text { National School of Mineral } \\
\text { Industry }\end{array}$ & Morocco & $\begin{array}{l}\text { Performance Measurement model } \\
\text { Moroccan automotive suppliers } \\
\text { Analytical Hierarchy Process }\end{array}$ \\
\hline & Noureddine EL ALAMI & $\begin{array}{l}\text { University Mohammed V- } \\
\text { Agdal }\end{array}$ & Morocco & $\begin{array}{c}\text { Performance Measurement model } \\
\text { Moroccan automotive suppliers } \\
\text { Analytical Hierarchy Process }\end{array}$ \\
\hline
\end{tabular}

As shown in Table 1, the authors built partnerships with other researchers from different institutions but not from different countries. These include "Center for Advanced Studies in Engineering and 
Institute of Development Economics" in Pakistan, also "University Mohammed V-Agdal" and "National School of Mineral Industry" in Morocco.

In addition, we identified 30 Journals in which the authors published their articles, the list is presented in appendix B. Indeed, the top 5 journals according to their impact factors (2017) are: "Journal of Cleaner Production", transdisciplinary journal focusing on cleaner production, environment, and sustainability study. "International Journal of Production Economics" emphases on topics discussing the interface between engineering and management. All features of the topic in ad equation with industrial and process manufacturing are covered. "Supply Chain Management: An International Journal", aims to extend the limits of supply chain study and practice. Therefore, research results must demonstrate international relevance and total impact on theory and practice. "Expert Systems with Applications" is specializing in the exchange of information related to expert and intelligent systems applied in industry and governments around the world. "International Journal of Operations \& Production Management" examines opportunities, challenges, and frontiers of emerging and implementing strategies, systems, processes and practices in SCM.

Regarding co-occurrence, there are 266 keywords with at least 2 occurrences, 16 elements were presented, forming 4 clusters of 104 links as illustrated in Fig. 5. Therefore, clusters have two important themes when using the keywords "performan*", "measure*" and "Automotive", the first "automotive sector" and the second "supply chain management".

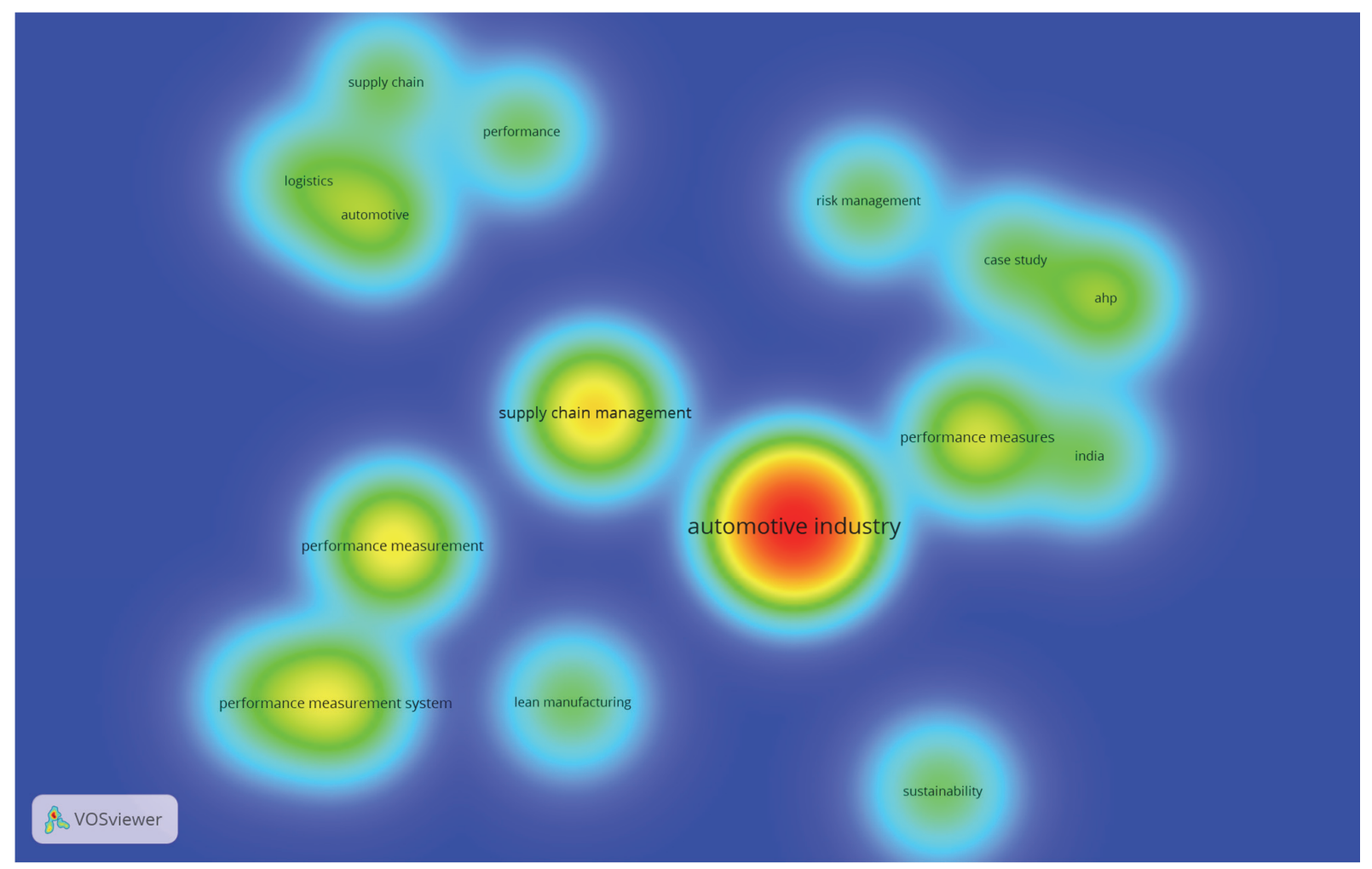

Fig. 5. Keyword co-occurrence

The last result that can be presented from selected articles is the number of citation that corresponds to the identification of the number of times the paper has been used by other scientific articles. Indeed, 25 articles were identified with at least one quote in the Scopus database (details presented in Appendix A). There are two ways of verifying citations as explained by Mingers and Loet (2015): The first is the Web of Science database (WoS) or the Scopus database, which are subscribed and offer different levels of accessibility according to the amount of payment, leading to differentiated access for researchers. The second is from Google Scholar, more easily accessible and provides free access to resources). In 
this article, the authors have opted for the Scopus database since the laboratory has access to this database via the IMIST website ${ }^{1}$. The articles with more than 15 citations are shown in Fig. 6.

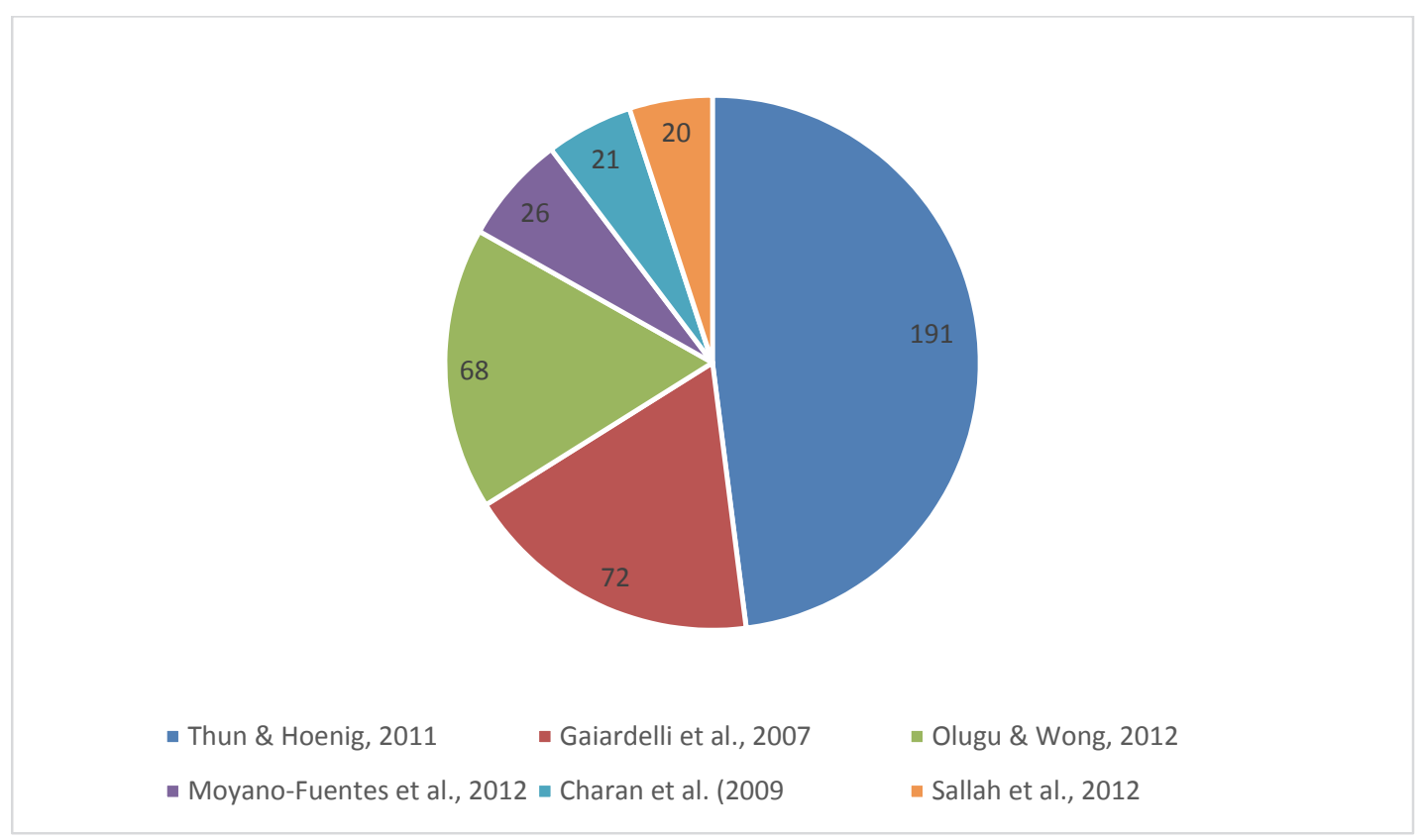

Fig. 6. Most cited articles.

As we can observe from the results of Fig. 6, the study by Thun and Hoenig (2011) received 191 citations. The paper classifies supply chain risks by analyzing their potential influence on the SC. It presents the empirical analysis for supply chain risk management (SCRM) based on an investigation of 67 manufacturing companies in the German automotive industry. Gaiardelli et al. (2007) obtained 72 citations. The article develops an empirical application based on a proposed integrated framework for measuring the performance of the aftermarket network. This study is applied to two automotive companies and their official maintenance network. Olugu and Wong (2012) obtained 68 citations. The authors use Visual Basic.Net to develop an appropriate expert fuzzy system based on rules for evaluation. The subsequent PMS was assessed using a case study in the automobile industry. MoyanoFuentes et al. (2012) presented 26 citations. The article discusses the connection between the level of partnership between suppliers and customers, and its effect on the integration of information with customers. Charan et al. (2009) presented 21 citations. The authors used the Interpretive Structural Modeling (ISM) framework to explore the correlation between the different obstacles to the implementation of the PMS in the Indian automotive supply chains. Salleh et al. (2012) obtained 20 citations. Total quality management (TQM) and lean manufacturing (LM) are two topics addressed by the authors in their study. They also applied their research in the Malaysian automotive industry. The paper examines critical success and failure factors of the implementation phase based on established quality criteria. The study by Behrouzi and Wong (2011) has received 20 citations. The work identifies the underlying the performance components of the lean supply chain of small and medium-sized (SME) enterprises in the Iranian automotive industry with a special focus on related metrics. Charan ( 2012) obtained 18 citations. The article provides evidence on the progress of an OEM's supply chain performance initiatives in India. Finally, the work developed by Marodin et al. (2016) was cited 15 times. The article aims to study the implementation models of lean manufacturing and the connection between three contextual factors (firm size, supply chain positions, and the duration of the lean initiative) and the adoption of lean manufacturing practices in automotive supply chain firms in Brazil.

\footnotetext{
${ }^{1}$ IMIST: Listed among the achievements programmed in the five-year development plan 2000-2004 with an investment budget of 150 million dirhams, the Moroccan Institute of Scientific and Technical Information (IMIST) reports to the National Center for Scientific and Technical Research (CNRST) as a research operator (www.imist.ma).
} 


\section{Discussion}

We verified that out of the 30 selected articles; $34 \%$ are theoretical, $66 \%$, empirical, and the publications were between 2007 and 2018. Since the search of the database was conducted until August 2018, our search did not find articles corresponding to the subject covered in the two years 2010 and 2013. Fig. 7 shows the annual distribution of articles by theoretical and empirical nature.

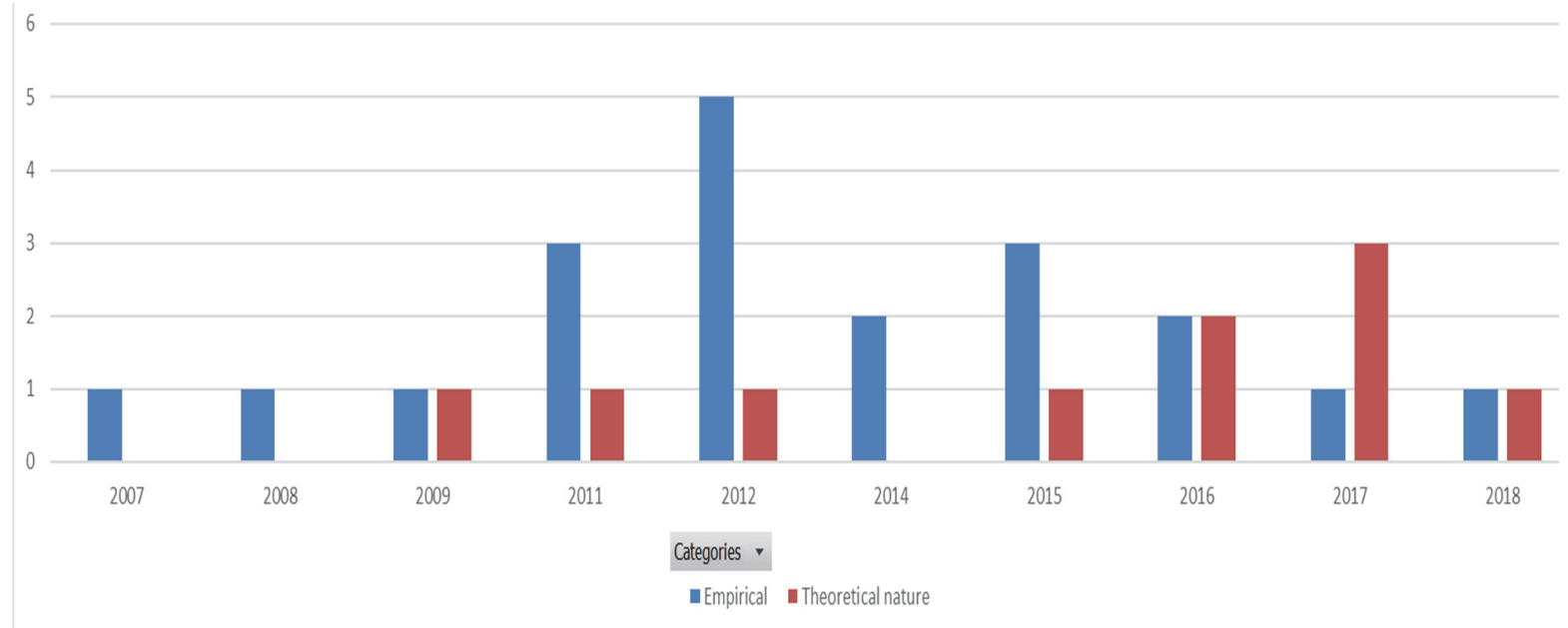

Fig. 7. Articles' classification and publication period.

Fig. 8 displays the research methods used in the 30 articles. We can assert that $66 \%$ of the articles are of empirical nature, like the research conducted by Thun and Hoenig (2011) in the German automotive and Moyano-Fuentes et al. (2012) who reports from the Spanish automotive industry. 34\% of the studies are literature reviews and 33\% multiple case studies, already described in the literature, as presented data from the companies In Pakistan, Spanish and Moroccan automotive industries. 13\% were conducted based on the questionnaire survey and explanatory factors as Habidin and al'work. ( Habidin \& Mohd Fuzi, 2015).

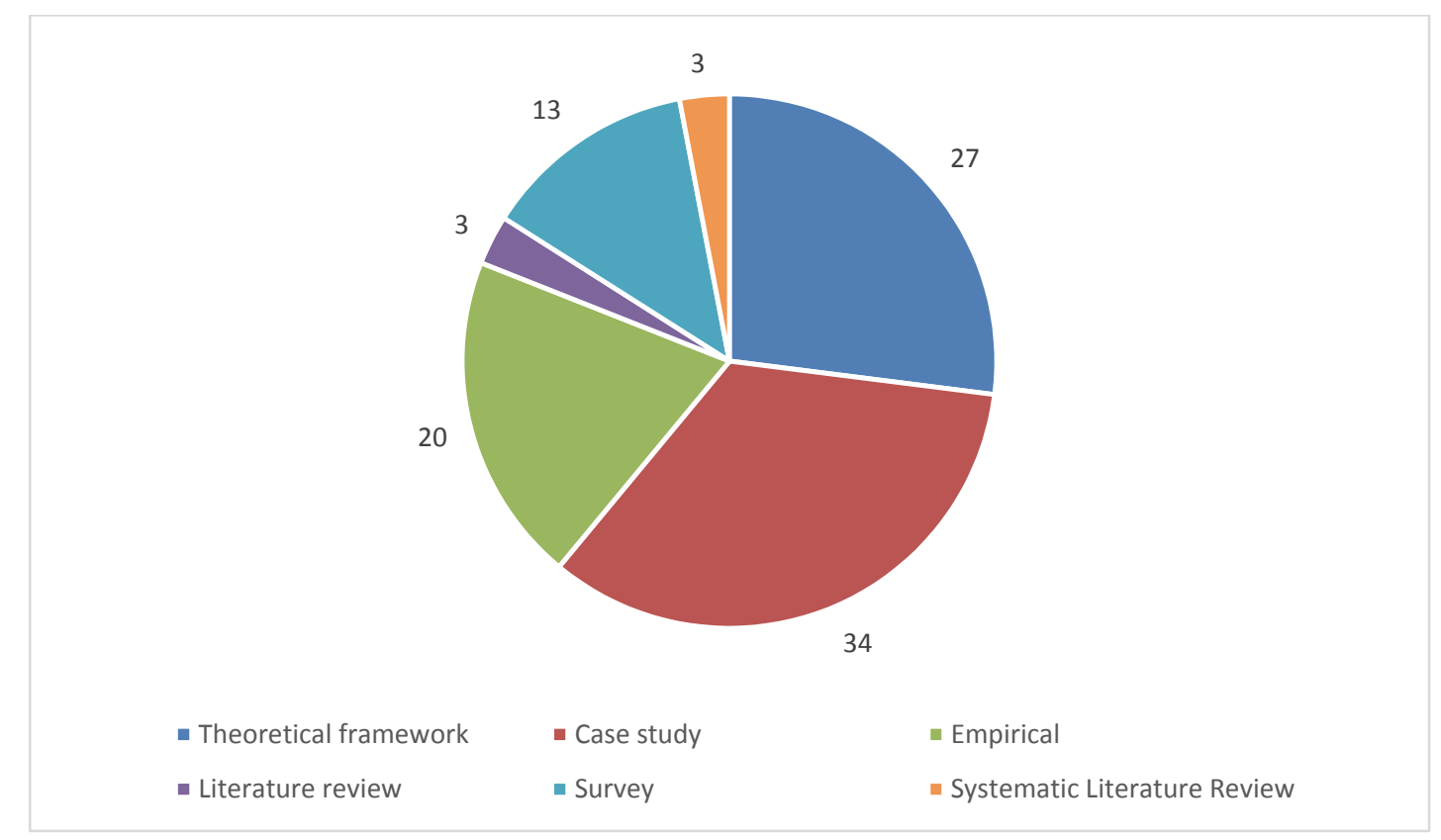

Fig. 8. Research Methods

\subsection{Case studies}

Case studies let to reach an advanced conceptual validity throughput its main process that is based on the identification and the measurement of the indicators which best reflect the theoretical concepts that 
the investigator works on George and Bennett (2004). In this section, automotive industry case studies are presented;

Cagnin et al. (2016) show that the case study organization has established criteria for supplier selection, their study's objective was to detect potential risks in the value chain before the project is awarded by the supplier, but the recent practice can also be developed by using as a reference the comparative method carried out in their research. According to them, the method for supplier selection chosen for comparison has some advantages one of them is due to the one technique used to be a common systematic in the automotive sector.

Kumar and Chandra (2017) demonstrated that Fuzzy AHP (Mon et al., 1994) approach can be utilized to rank and classify the sustainability indicators for improving sustainability performance. A sensitivity analysis has been executed to know the changes in the scopes of sustainability with the change in one of the sustainability scopes. The possible sustainability indicators have been recognized using literature review and experts' opinion.

El-Khalil (2015) explains that the investment cost and process development are the two major challenges facing operations managers in the manufacturing firm. His research was motivated by a manager's recommendation among the Big Three firms (GM, Ford, Chrysler LLC) to increase the effective performance. The data used in making the simulation model was getting from one of the assembly facilities that produce three different vehicles over a period of one year. According to him, his research lets managers gain a wider perspective on discrete simulation capacity to simulate complicated systems and present different process development alternatives. Chahid et al. (2014) discuss in their article the relevance of improving human skills and production system's efficiency for Moroccan car manufacturers development. Wong and Olugu (2012) indicate that the system of performance evaluation is essential for reaching a successful closed-loop supply chain in the automotive sector. The closed-loop value chain management has been well-known as an efficient, effective and economical strategy emphasize towards environmentally sustainable practices in manufacturing firms. The fuzzy procedures and arithmetic used were designated in their research. Furthermore, in the automotive sector, the subsequent performance measurement implementation was the main focus of a case study. Charan (2012) examines a case study of one company of a primary original equipment manufacturer in India, to highlight the status of supply chain performance initiatives in its supply chain. His case study organization was engaged various initiatives for improving supply chain performance, such as vendor managed inventory and dealer management system. Nevertheless, the issues that need attention, according to him contain a measurement of the vendor's performance on criteria which have supply chain alignment, as well as linking dealers' point of sale information to retailers; this way links the supply chain as an entire. Emphasis should be positioned on second and third-tier suppliers, because they are a source of the majority of quality problem.

Neto and Pires (2012) explain that the supply chain performance measurement has the tendency to reinforce the cooperative relations. The systems provided by the some experts have a higher aggregate value, high specificities and also have characteristics relating to the safety of the vehicle. According to them, the manufacturer has a higher control over the performance evaluation.

Sarwar et al. (2012) emphases that the operational use of technology can significantly improve the productivity of Pakistani manufacturing industries. The suggestion of their research is to select the recurrent condition of productivity in the automotive manufacturing firm of Pakistan and to point out the potential areas for enhancing the productivity. This study's outcomes reveal weak work performance and productivity, leading to negative result for these firms.

Gaiardelli et al. (2007) propose an integrated approach for the after-sales process performance measurement, they provide an application for two automotive firms particularly for the official service linkage. Also, they argued that to reach a strategic reliability it is necessary that the performance measurement tool of the several entities should be associated. 
In summary, based on the literature; the various recommendations of case studies reviews are as follows:

- The potential risks in the value chain should be identified before the project is awarded by the supplier.

- The Fuzzy AHP approach may be employed to rank and classify sustainability indicators to improve sustainability performance.

- The investment cost and the process development are the two main challenges faced by the manufacturing company's operations managers to increase the effective performance.

- The production efficiency improvement and human skills enhancement should be given the top priority in the automotive industry.

- The performance evaluation system is quite essential to reach a successful closed-loop automotive value chain.

- The dealer and inventory management system is among the most important initiatives to improve the performance of the automotive value chain.

- The operational use of technology can make manufacturing industries productivity better. In fact, both weak labor performance and productivity, result in enormous losses and inactif growth of these firms.

- The performance measurement mechanism of several partners in the supply chain should be combined to achieve strategic reliability.

\subsection{Theoretical frameworks}

Some argue that the theory is not highly required because research should focus on answering narrow questions that may be an interest for practitioners. However, theoretical investigation serves the educational discipline progress and evolution. The theory can guide research, practice, curriculum development, evaluation, and contribute to the advancement of effective teaching tactics and strategies (Abraham, 2008). In this section, the studies based on theoretical frameworks in the automotive sector are highlighted;

Han et al. (2017) argue that the conceptual framework examining the measurement and effectiveness of the partnership within supply chain can be seen as the point at which theory meets practice. By providing an in-depth case study account, in which the criteria of particular relevance in the multicultural supply chain partnership are both identified and addressed, their research provides an original and much-needed achievement to the knowledge. Their study has discovered and developed the dynamic kind of the supply chain partnership with the Chinese automotive firm. Actors from different business entities, manufacturing industries and supply chains see that seeking supply chain partnership may employee the framework and refine the criteria internally to evaluate the potential partners of the suggested partnership.

Petrillo et al. (2018) tried to set a performance measurement system (PMS) for the successful assessment of world class manufacturing (WCM). Their study developed a management model to optimize logistics performance, taking benefits from the WCM tools. The ultimate goal of the model was Logistic \& Customer Service optimisation and company performance measurement. According, the model was successfully tested in an Italian automotive supplier company. The first three reactive steps of the WCM model were implemented in the company's warehouse.

Dörnhöfer and Günthner (2017) performed a systematic review on an industry. They first examined the literature based on PMS design presented in the academic literature. Second they utilized to validate the design aspects highlighted in the literature through presenting the industry perspective. 
Jasiński et al. (2016) provided a framework for automotive sustainability assessment throughout calculation criteria selecting from literature and then filtered them in an interview study with automotive industry experts. Their framework offers a comprehensive and whole sight of the sustainability performance of automobiles. It presents multi-dimensional effects on cars which improve engineers' ability to make innovative decisions during the product development stage that reflect sustainability.

Drohomeretski et al. (2015) identified the most recurrently performance measures and sustainability practices which have been adopted in the automotive industries. In their point of view, its reflect the level of the automotive industry implication regarding to sustainability concerns, therefore its let to implement and examine the sustainable actions performed within companies, and contribute to the formulation of performance measures that meet the scopes of sustainability according to the classification process established in their research.

Salleh et al. (2012) explored the opportunity of integrating total quality management (TQM) and lean manufacturing (LM) in a new approach to be offered for adoption in Malaysian automotive sector. More benefits are expected from the synergy of TQM and LM combination, particularly in reducing time and effort. Their research provides information on types of models, practices and failure or success key factors of others that have applied the systems individually. Hadiguna et al. (2011) show that many automobile industries should create appropriate measures for operational green supply chain performance measurement. Accordingly, they haven't succeeded in supply chain management because of their failure in performance measurement and supply chain integration. Charan et al. (2009) investigate the implementation obstacles of supply chain performance measurement (SCPM) in the Indian automotive firms. Their results specify that lack of awareness related to SCPM system and the lack of top management's dedication is the major significant obstacles. Furthermore, the results exposed that existence of important dependence among the obstacles. Lastly, various approaches were delivered for improving Indian automotive supply chains performance.

Briefly, the theoretical frameworks highlighted in this part aim to:

- Develop a business model to optimize logistics performance, leveraging web content management tools.

- Optimize the logistics and customer service pillar by measuring the improvement of the company performance.

- Develop a perspective for the automotive industry through combining a systematic literature review and an industry survey.

- Develop a comprehensive evaluation framework for automotive sustainability.

- Identify the common performance metrics and the sustainable practices in automotive industries.

- Integrate TQM and LM into a new approach and its application in the automotive sector.

- Identify the main barriers to supply chain development.

\subsection{Empirical studies and survey methods}

Sample surveys currently face significant challenges that have important implications for both the method and its use in problem analysis (Kennedy \& Vargus, 2001). In this last section, the various authors who chose the empirical and the survey-based studies in their analysis will be presented;

Fuchs et al. (2018) worked on the interactions among IT capabilities, supply chain capabilities, and supplier performance using empirical data from automotive providers in Europe. Their results show a solid relationship between these three outlooks. Data capabilities contribute to value chain capabilities through a favorable influence on practical capabilities. In addition, the results highlight the interest of car manufacturers to promote the implementation of IT as a performance factor. 
Cao et al. (2015) emphasized that for the automotive manufacturing; sustainability needs multidisciplinary approach containing product design, material development, pollution prevention, and social compliance so as to deal with sustainability challenges and to ensure an overall supply chain engagement toward developments. Their study created challenges to environmental sustainability and social responsibility at all sustainable uniform progress and planned production's phases.

Thun and Hoenig (2011) purposed an empirical investigation of SC risk management practices. The work focused on a survey conducted at 67 automotive manufacturing plants in Germany. After they examined the SCs' vulnerability in general and investigated SCs' key factors of risks, evaluated SC risks possibility to occur and their effect's extent on the SC. Leeuw and Beekman (2008) presented a performance measurement empirical survey's outputs in a spare parts automotive value chain in particularly in the after sales market. The LogistiQual model was used and the applicability of different types of performance measures was discussed. Marodin et al. (2016) conducted a survey in 64 company from the automotive SC in Brazil. They demonstrated how lean practices were applied at different positions within the SC, and the patterns of application often followed. It is also estimated lean in the context of developing countries like Brazil.

Habidin and Nursyazwani (2015) used confirmatory feature analysis and examined the sustainable performance measures for automotive in Malaysia. In their study, sustainable performance measures concentrated on environmental sustainability, corporate social responsibility sustainability and economic sustainability. Confirmatory feature analysis was engaged to check the model on a sample of 227 respondents from automotive sector in Malaysia. The results of their work show that three features for sustainable performance measures for the Malaysian automotive sector were valid and consistent.

Moyano-Fuentes et al. (2012) revealed that even if greater cooperation with suppliers did not affect the intensity of adoption of logistics performance, greater cooperation with customers had an important effect. Their analysis focuses on an application to leading suppliers for automotive equipment manufacturers in the Spain industry (84 plants). Ong and Heng (2008) used multivariate analysis of questionnaire data to rigorously establish the existence of two categories of the performance measurement system with features that reflect those expected by examining the theoretical literature. Their research pointed out that the situation on a performance measurement system in a high technology industry of a developing country seems similar to that discussed in the literature for industries in Western and developed economies.

In conclusion, the main conclusions from articles discussed in this part are as follows:

- The coordination between IT capabilities, supply chain capabilities, and vendor performance, means that the car manufacturers have an interest in promoting the implementation of information technology as a performance factor.

- For automotive manufacturing, Sustainability necessitates a multi-dimensional vision encompassing product design, material development, pollution prevention and social compliance.

- Identifying value chain risks is performed by assessing their probability and effect on the SC.

- After applying lean practices at different points in the SC, it appears that the often applied application models are considered lean in developing countries context.

- Sustainable performance measures are based on environmental, social and economic dimensions.

- It was revealed that the situation of a PMS in the high-tech industry in a developing country seemed similar to that described in the literature for the industries of western and developed economies. 


\section{Conclusions}

This article has identified a literature between 2007 and 2018 specializing in performance measurement in the automotive sector using the Scopus and Google Scholar databases. A structured review of the literature, using bibliometric analysis, was performed using the ProKnow-C method. As a first result of the bibliometric analysis, the Journal of Cleaner Production has the largest number of articles published on the subject studied. Second, the most prolific authors are Chahid et al. (2014). The authors are partners for other researchers from different institutions, but not from different countries, as identified in 26 clusters of co-authorship the authors. Using the keywords "performan*", "measure*" and "Automotive", two thematic clusters were identified: "automotive sector" and "supply chain management". In addition, 25 articles were noted with at least one citation from the Scopus database among the 30 selected articles.

Based on the content analysis, it was verified that compared with the evaluation and measurement process; automotive sector performance is well structured. Indeed, the conceptual framework examining the measurement and effectiveness of partnership in the SC can be seen as the point where theory meets practice. In the multicultural business environment, SC's partnership development may be based initially on the performance measurement framework and the criteria refinement internally to assess potential partners in the proposed partnership.

Several studies have developed a management model to optimize logistics performance, through using Web content management tools. The ultimate aim is to optimize the Logistics and Customer Service pillar and to measure the performance improvement of the companies studied. Moreover, the authors have developed a comprehensive evaluation framework for automotive sustainability which is based on criteria constructed from both theory and practice. A global view of automotive performance in terms of sustainability has been provided. In addition, it was possible to extract practices and performance measures by providing an overview of the automotive industry's performance in sustainable development. For this reason, many automotive companies necessitate to establish appropriate measures to effectively measure the performance of the green supply chain.

The selected studies have shown that the lack of awareness of the PMS and the lack of dedication of management are the major obstacles. The results also have indicated the existence of a strong connection between obstacles. Finally, various guidelines are provided to improve the automotive SC performance.

Among the limitations of this study were the sample field used based solely on journals indexed by Scopus and Google scholar databases excluding theses, dissertations and books. So as prospect for future research we suggest to analyze a performance measurement tool in the automotive industry and adapts it to the context and specificity of this sector which has a very complicated logistics chain. A model like SCOR, for example, may be a subject of several research projects given its importance and the lack of literature in relation to this model and its application in the automotive sector (Lemghari et al., 2018b, 2018a).

\section{References}

Abraham, M. R. (2008). Importance of a theoretical framework for research. ACS Symposium Series, 976, 47-66.

Afonso, M. H., Souza, J. D., Ensslin, S. R., \& Ensslin, L. (2011). Como construir conhecimento sobre o tema de pesquisa? Aplicação do processo Proknow-C na busca de literatura sobre avaliação do desenvolvimento sustentável. Revista de Gestão Social e Ambiental, 5(2), 47-62.

Aracioğlu, B., Zalluhoğlu, A. E., \& Candemir, C. (2013). Measuring and evaluating performance within the strategic management perspective: A study on performance measurement of a seafood company. Procedia-Social and Behavioral Sciences, 99, 1026-1034.

Beamon, B. M. (1998). Supply chain design and analysis:: Models and methods. International journal of production economics, 55(3), 281-294.

Behrouzi, F., \& Wong, K. Y. (2011). An investigation and identification of lean supply chain 
performance measures in the automotive SMEs. Scientific research and essays, 6(24), 5239-5252.

Bolstorff, P., \& Rosenbaum, R. (2011) Supply Chain Excellence: A Handbook for Dramatic Improvement Using the SCOR Model. Third Edition. Third Edit. AMACOM; New York; NY.

Brandão, H. P., \& Guimarães, T. D. A. (2001). Gestão de competências e gestão de desempenho: tecnologias distintas ou instrumentos de um mesmo construto?. Revista de Administração de empresas, 41(1), 8-15.

Cagnin, F., Oliveira, M. C., Simon, A. T., Helleno, A. L., \& Vendramini, M. P. (2016). Proposal of a method for selecting suppliers considering risk management: An application at the automotive industry. International Journal of Quality \& Reliability Management, 33(4), 488-498.

Cao, H., Dickson, M. A., Cobb, K., Carper, M., Scudder, C., \& Wong, C. (2015). Applying a sustainability performance measurement tool in designing and developing automotive employee uniforms. International Journal of Fashion Design, Technology and Education, 8(2), 78-86.

Carr, J. E., \& Hasan, M. (2009). An empirical study of performance measurement systems in New Zealand manufacturing companies. Australian Journal of Mechanical Engineering, 7(1), 45-52.

Chahid, M. T., El Alami, J., Soulhi, A., \& El Alami, N. (2014). Performance Measurement Model for Moroccan Automotive Suppliers Using PMQ and AHP. Modern Applied Science, 8(6), 137.

Charan, P. (2012). Supply chain performance issues in an automobile company: a SAP-LAP analysis', Measuring Business Excellence, 16(1), 67-86.

Charan, P., Shankar, R., \& Baisya, R. K. (2009). Modelling the barriers of supply chain performance measurement system implementation in the Indian automobile supply chain. International Journal of Logistics Systems and Management, 5(6), 614.

Creswell, J. W. (2007). Projeto de pesquisa: métodos qualitativo, quantitativo e misto, traduçao Luciana de Oliveira da Rocha.

Croxton, K. L., Garcia-Dastugue, S. J., Lambert, D. M., \& Rogers, D. S. (2001). The supply chain management processes. The International Journal of Logistics Management, 12(2), 13-36.

Dörnhöfer, M., \& Günthner, W. A. (2017). A research and industry perspective on automotive logistics performance measurement. The International Journal of Logistics Management, 28(1), 102-126.

Dörnhöfer, M., Schröder, F., \& Günthner, W. A. (2016). Logistics performance measurement system for the automotive industry. Logistics Research, 9(1), 11.

Drohomeretski, E., da Costa, S. E. G., de Lima, E. P., \& de Oliveira Neves, T. R. (2015). The Application of sustainable practices and performance measures in the automotive industry: a systematic literature review. Engineering Management Journal, 27(1), 32-44.

Eccles, R. (1991). The performance measurennent manifesto. Harvard business review, 69(1), 131137.

van Eck, N., \& Waltman, L. (2009). Software survey: VOSviewer, a computer program for bibliometric mapping. Scientometrics, 84(2), 523-538.

El-Khalil, R. (2015). Simulation analysis for managing and improving productivity: a case study of an automotive company. Journal of Manufacturing Technology Management, 26(1), 36-56.

Ensslin, L., \& Ensslin, S. R. (2012). Uma análise bibliométrica da literatura sobre estratégia e avaliação de desempenho. Gestão \& Produção, 19(1), 59-78.

Ensslin, S. R., Ensslin, L., de Oliveira Lacerda, R. T., \& de Souza, V. H. A. (2014). Disclosure of the state of the art of performance evaluation applied to project management. American Journal of Industrial and Business Management, 4(11), 677.

Eskafi, S., Roghanian, E., \& Jafari-Eskandari, M. (2015). Designing a performance measurement system for supply chain using balanced scorecard, path analysis, cooperative game theory and evolutionary game theory: A Case Study. International Journal of Industrial Engineering Computations, 6(2), 157-172.

Eswaramurthi, K. G., \& Mohanram, P. V. (2013). Improvement of manufacturing performance measurement system and evaluation of overall resource effectiveness. American Journal of Applied Sciences, 10(2), 131.

Habidin, N. F., Zubir, A. F. M., Fuzi, N. M., Latip, N. A. M., \& Azman, M. N. A. (2015). Sustainable Performance Measures for Malaysian Automotive Industry. World Applied Sciences Journal, 33(6), 
1017-1024

Fuchs, C., Beck, D., Lienland, B., \& Kellner, F. (2018). The role of IT in automotive supplier supply chains. Journal of Enterprise Information Management, 31(1), 64-88.

Gaiardelli, P., Saccani, N., \& Songini, L. (2007). Performance measurement of the after-sales service network-Evidence from the automotive industry. Computers in Industry, 58(7), 698-708.

George, A. L., \& Bennett, A. (2005). Case studies and theory development in the social sciences. mit Press.

Gholampour, G., Rahman, A., \& Abdul, B. I. N. (2015). The evaluation of operational performance of supply chain at automotive industry. Journal of Theoretical \& Applied Information Technology, 73(3).

Goldenstein, M., \& Casotti, B. P. (2008). Panorama do setor automotivo: As mudanças estruturais da indústria e as perspectivas para o Brasil. BNDES Setorial, 28, 147-188.

Gunasekaran, A., \& Kobu, B. (2007). Performance measures and metrics in logistics and supply chain management: a review of recent literature (1995-2004) for research and applications. International journal of production research, 45(12), 2819-2840.

Hadiguna, R. A., Jaafar, H. S., \& Mohamad, S. (2011). Performance measurement for sustainable supply chain in automotive industry: a conceptual framework. International Journal of Value Chain Management, 5(3-4), 232-250.

Han, W., Huang, Y., \& Macbeth, D. (2018). Performance measurement of cross-culture supply chain partnership: a case study in the Chinese automotive industry. International Journal of Production Research, 56(7), 2437-2451.

Horner, M. (2006). Performance measurement. Measurement, 1(4), 43-54.

Humphrey, J., \& Memedovic, O. (2003). The global automotive industry value chain: What prospects for upgrading by developing countries. SSRN doi: 10.2139/ssrn.424560.

Jasiński, D., Meredith, J., \& Kirwan, K. (2016). A comprehensive framework for automotive sustainability assessment. Journal of Cleaner Production, 135, 1034-1044.

Kaplan, R. S., \& Norton, D. P. (1992). The balanced scorecard - measures that drive performance the balanced scorecard-Measures that drive performance. Harvard Business Review, 71-9.

Kennedy, J. M., \& Vargus, B. (2001). Challenges in survey research and their implications for philanthropic studies research. Nonprofit and Voluntary Sector Quarterly, 30(3), 483-494.

Kennerley, M., \& Neely, A. (2003). Measuring performance in a changing business environment. International Journal of Operations and Production Management, 23(2), 213-229.

Kumar, D., \& Garg, C. P. (2017). Evaluating sustainable supply chain indicators using fuzzy AHP: Case of Indian automotive industry. Benchmarking: An International Journal, 24(6), 1742-1766.

Laurence Bardin (2016) Análise de Conteúdo. São Paulo: Edições 70, São Paulo: Edições 70. Available at: https://madmunifacs.files.wordpress.com/2016/08/anc3a1lise-de-contec3badolaurence-bardin.pdf.

Lebas, M. J. (1995). Performance measurement and performance management. International Journal of Production Economics, 41(1-3), 23-35.

Leeuw, S. De., \& Beekman, L. (2008). Supply chain-oriented performance measurement for automotive spare parts. International Journal of Automotive Technology and Management, 8(1), 56.

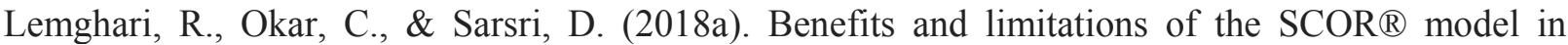
Automotive Industries. In MATEC Web of Conferences (Vol. 200, p. 00019). EDP Sciences.

Lemghari, R., Okar, C., \& Sarsri, D. (2018b). Supply Chain Performance Measurement: A Case Study about Applicability of SCOR ${ }^{\circledR}$ Model in Automotive Industry Firm. In MATEC Web of Conferences, vol. 200, p. 00016. EDP Sciences, 2018.

Marodin, G. A., Frank, A. G., Tortorella, G. L., \& Saurin, T. A. (2016). Contextual factors and lean production implementation in the Brazilian automotive supply chain. Supply Chain Management: An International Journal, 21(4), 417-432.

Marwah, A. K., Thakar, G., \& Gupta, R. C. (2012). Implications of performance measurement approaches on supply chain performance. In National Conference on Emerging Challenges for Sustainable Business (pp. 1731-1760). 
Mingers, J., \& Leydesdorff, L. (2015). A review of theory and practice in scientometrics. European journal of operational research, 246(1), 1-19.

Mon, D. L., Cheng, C. H., \& Lin, J. C. (1994). Evaluating weapon system using fuzzy analytic hierarchy process based on entropy weight. Fuzzy sets and systems, 62(2), 127-134.

Moyano-Fuentes, J., Sacristán-Díaz, M., \& Jose Martinez-Jurado, P. (2012). Cooperation in the supply chain and lean production adoption: evidence from the Spanish automotive industry. International Journal of Operations \& Production Management, 32(9), 1075-1096.

Neely, A., Mills, J., Platts, K., Richards, H., Gregory, M., Bourne, M., \& Kennerley, M. (2000). Performance measurement system design: developing and testing a process-based approach. International journal of operations \& production management, 20(10), 1119-1145.

Neely, A., Gregory, M., \& Platts, K. (1995). Performance measurement system design: a literature review and research agenda. International journal of operations \& production management, 15(4), 80-116.

Neto, M. S., \& Pires, S. R. I. (2012). Performance measurement in supply chains: A study in the automotive industry. Gestao e Producao, 19(4), 733-746.

Oliveira, A. S., de Barros, M. D., de Carvalho Pereira, F., Gomes, C. F. S., \& da Costa, H. G. (2018). Prospective scenarios: A literature review on the Scopus database. Futures, 100, 20-33.

Olugu, E. U., \& Wong, K. Y. (2012). An expert fuzzy rule-based system for closed-loop supply chain performance assessment in the automotive industry. Expert Systems with Applications, 39(1), 375384.

Ong, T. S., \& Teh, B. H. (2009). Factors influencing the design and use of performance measurement systems in the Malaysian electrical and electronics industry. International Journal of Economics and Management, 2(2), 437-457.

Osati, M., \& Manouchehr, M. (2016). Performance measurement of electricity suppliers using PROMETHEE and balance scorecard. Management Science Letters, 6(6), 387-394.

Petrillo, A., De Felice, F., \& Zomparelli, F. (2017). Performance measurement for world-class manufacturing: a model for the Italian automotive industry. Total Quality Management \& Business Excellence, 1-28.

Phongpetra, V., \& Johri, L. M. (2011). Impact of business strategies of automobile manufacturers in Thailand. International Journal of Emerging Markets, 6(1), 17-37.

Ptak, C. A., \& Schragenheim, E. (2003). ERP: tools, techniques, and applications for integrating the supply chain. Crc Press. doi: 10.1037/023990.

Ab Rahman, M. N., Khamis, N. K., Zain, R. M., Deros, B. M., \& Mahmood, W. H. W. (2010). Implementation of $5 \mathrm{~S}$ practices in the manufacturing companies: A case study. American Journal of Applied Sciences, 7(8), 1182-1189.

Saleh, A. (2012). Mendeley. Journal of the Canadian Health Libraries Association, 33(1), 29-30.

Salleh, N. A. M., Kasolang, S., \& Jaafar, H. A. (2012). Review study of developing an integrated TQM with LM framework model in Malaysian automotive industry. The TQM Journal, 24(5), 399-417.

Zahoor Sarwar, S., Ishaque, A., Ehsan, N., Saeed Pirzada, D., \& Moeen Nasir, Z. (2012). Identifying productivity blemishes in Pakistan automotive industry: a case study. International Journal of Productivity and Performance Management, 61(2), 173-193.

Schulze, A., Paul MacDuffie, J., \& Täube, F. A. (2015). Introduction: knowledge generation and innovation diffusion in the global automotive industry-change and stability during turbulent times. Industrial and Corporate Change, 24(3), 603-611.

Sillanpää, I. (2010) Supply chain performance measurement in the manufacturing industry. A single case study research to develop a supply chain performance measurement framework, University of Oulu. Acta Univ. Oul.

Sturgeon, T., Van Biesebroeck, J., \& Gereffi, G. (2008). Value chains, networks and clusters: Reframing the global automotive industry. Journal of Economic Geography, 8(3), 297-321.

Thun, J. H., \& Hoenig, D. (2011). An empirical analysis of supply chain risk management in the German automotive industry. International Journal of Production Economics, 131(1), pp. 242-249.

Vanalle, R. M., \& Santos, L. B. (2014). Green supply chain management in Brazilian automotive 
sector', Management of Environmental Quality: An International Journal, 25(5), 523-541.

Vaz, C., Rauen, T., \& Lezana, Á. (2017). Sustainability and innovation in the automotive sector: A structured content analysis. Sustainability, 9(6), 880.

Waggoner, D. B., Neely, A. D., \& Kennerley, M. P. (1999). The forces that shape organisational performance measurement systems: An interdisciplinary review. International Journal of Production Economics, 60, 53-60.

\section{Appendix A}

\section{Table A1}

List of articles aligned with the theme and citation.

\begin{tabular}{|c|c|c|c|c|}
\hline Authors & Article title & Year & $\begin{array}{l}\text { Citation } \\
\text { Indexes }\end{array}$ & Reference \\
\hline $\begin{array}{l}\text { Divesh Kumar, Chandra } \\
\text { Prakash Garg }\end{array}$ & $\begin{array}{c}\text { Evaluating sustainable supply } \\
\text { chain indicators using Fuzzy AHP: } \\
\text { Case of Indian automotive } \\
\text { industry }\end{array}$ & 2017 & 1 & (Kumar and Garg, 2017) \\
\hline $\begin{array}{l}\text { Paolo Gaiardelli, Nicola } \\
\text { Saccani, Lucrezia Songini }\end{array}$ & $\begin{array}{l}\text { Performance measurement of the } \\
\text { after-sales service network- } \\
\text { Evidence from the automotive } \\
\text { industry }\end{array}$ & 2007 & 72 & (Gaiardelli, Saccani and Songini, 2007) \\
\hline $\begin{array}{c}\text { Everton Drohomeretski, } \\
\text { Sergio E. Gouvea da Costa, } \\
\text { Edson Pinheiro de Lima \& } \\
\text { Tainan } \\
\text { Rodrigues de Oliveira Neves }\end{array}$ & $\begin{array}{l}\text { The Application of Sustainable } \\
\text { Practices and Performance } \\
\text { Measures in the Automotive } \\
\text { Industry: A Systematic Literature } \\
\text { Review }\end{array}$ & 2015 & 1 & (Drohomeretski et al., 2015) \\
\hline $\begin{array}{l}\text { Ezutah Udoncy Olugu, } \\
\text { Kuan Yew Wong }\end{array}$ & $\begin{array}{l}\text { An expert fuzzy rule-based system } \\
\text { for closed-loop supply chain } \\
\text { performance assessment in the } \\
\text { automotive industry }\end{array}$ & 2012 & 68 & (Olugu and Wong, 2012) \\
\hline $\begin{array}{l}\text { Mário Sacomano Neto and } \\
\text { Sílvio R. I. Pires }\end{array}$ & $\begin{array}{l}\text { Performance Measurement in } \\
\text { Supply Chains: A Study in the } \\
\text { Automotive Industry }\end{array}$ & 2012 & 5 & (Neto and Pires, 2012) \\
\hline $\begin{array}{l}\text { Ong, T Z E S a N } \\
\text { Teh, Boon Heng }\end{array}$ & $\begin{array}{l}\text { Factors Influencing the Design and } \\
\text { Use of Performance Measurement } \\
\text { Systems in the Malaysian } \\
\text { Electrical and Electronics Industry }\end{array}$ & 2009 & 5 & (Ong and Teh, 2008) \\
\hline $\begin{array}{l}\text { Leeuw, Sander De } \\
\text { Beekman, Loek }\end{array}$ & $\begin{array}{l}\text { Supply chain-oriented } \\
\text { performance measurement for } \\
\text { automotive spare parts }\end{array}$ & 2008 & 4 & (Leeuw and Beekman, 2008) \\
\hline $\begin{array}{l}\text { Phongpetra, Vichak } \\
\text { Johri, Lalit M }\end{array}$ & $\begin{array}{c}\text { Impact of business strategies of } \\
\text { automobile manufacturers in } \\
\text { Thailand }\end{array}$ & 2011 & 7 & (Phongpetra and Johri, 2011) \\
\hline $\begin{array}{c}\text { Cao, Huantian } \\
\text { Dickson, Marsha A. } \\
\text { Cobb, Kelly } \\
\text { Carper, Martha } \\
\text { Scudder, Crescent } \\
\text { Wong, Crispin }\end{array}$ & $\begin{array}{l}\text { Applying a sustainability } \\
\text { performance measurement tool in } \\
\text { designing and developing } \\
\text { automotive employee uniforms }\end{array}$ & 2015 & 0 & (Cao et al., 2015) \\
\hline $\begin{array}{l}\text { Charan, Parikshit } \\
\text { Shankar, Ravi } \\
\text { Baisya, Rajat K. }\end{array}$ & $\begin{array}{l}\text { Modelling the barriers of Supply } \\
\text { Chain Performance Measurement } \\
\text { System implementation in the } \\
\text { Indian automobile supply chain }\end{array}$ & 2009 & 21 & (Charan, Shankar and Baisya, 2009) \\
\hline $\begin{array}{c}\text { Moyano-Fuentes, José } \\
\text { Sacristán-Díaz, Macarena } \\
\text { Martínez-Jurado, Pedro José }\end{array}$ & $\begin{array}{l}\text { Cooperation in the supply chain } \\
\text { and lean production adoption: } \\
\text { Evidence from the Spanish } \\
\text { automotive industry }\end{array}$ & 2012 & 26 & $\begin{array}{c}\text { (Moyano-Fuentes, Sacristán-Díaz and } \\
\text { Martínez-Jurado, 2012) }\end{array}$ \\
\hline $\begin{array}{c}\text { Thun, J H } \\
\text { Hoenig, Daniel }\end{array}$ & $\begin{array}{l}\text { An empirical analysis of supply } \\
\text { chain risk management in the } \\
\text { German automotive industry }\end{array}$ & 2011 & 191 & (Thun and Hoenig, 2011) \\
\hline $\begin{array}{c}\text { Han, Weixi } \\
\text { Huang, Yuan } \\
\text { Macbeth, Douglas }\end{array}$ & $\begin{array}{l}\text { Performance measurement of } \\
\text { cross-culture supply chain } \\
\text { partnership: a case study in the } \\
\text { Chinese automotive industry }\end{array}$ & 2017 & 0 & (Han, Huang and Macbeth, 2017) \\
\hline
\end{tabular}




\begin{tabular}{|c|c|c|c|c|}
\hline $\begin{array}{c}\text { Sarwar, Sheikh Zahoor } \\
\text { Ishaque, Azam } \\
\text { Ehsan, Nadeem } \\
\text { Pirzada, Danial Saeed } \\
\text { Nasir, Zafar Moeen }\end{array}$ & $\begin{array}{l}\text { Identifying productivity blemishes } \\
\text { in Pakistan automotive industry: a } \\
\text { case study }\end{array}$ & 2012 & 3 & (Sarwar et al., 2012) \\
\hline $\begin{array}{c}\text { Cagnin, Fernanda } \\
\text { Oliveira, Maria Celia } \\
\text { Simon, Alexandre Tadeu } \\
\text { Helleno, André Luis } \\
\text { Vendramini, Matheus } \\
\text { Phelipe }\end{array}$ & $\begin{array}{l}\text { Proposal of a method for selecting } \\
\text { suppliers considering risk } \\
\text { management: An application at the } \\
\text { automotive industry }\end{array}$ & 2016 & 3 & (Cagnin et al., 2016) \\
\hline $\begin{array}{c}\text { Hadiguna, Rika Ampuh } \\
\text { Jaafar, Harlina Suzanna } \\
\text { Mohamad, Sabariah }\end{array}$ & $\begin{array}{l}\text { Performance measurement for } \\
\text { sustainable supply chain in } \\
\text { automotive industry: a conceptual } \\
\text { framework }\end{array}$ & 2011 & 6 & (Hadiguna, Jaafar and Mohamad, 2011) \\
\hline $\begin{array}{c}\text { Jasiński, Dominik } \\
\text { Meredith, James } \\
\text { Kirwan, Kerry }\end{array}$ & $\begin{array}{l}\text { A comprehensive framework for } \\
\text { automotive sustainability } \\
\text { assessment }\end{array}$ & 2016 & 6 & (Jasiński, Meredith and Kirwan, 2016) \\
\hline $\begin{array}{l}\text { Fuchs, Christoph } \\
\text { Beck, Daniel } \\
\text { Lienland, Bernhard } \\
\text { Kellner, Florian }\end{array}$ & $\begin{array}{l}\text { The role of IT in automotive } \\
\text { supplier supply chains }\end{array}$ & 2018 & 0 & (Fuchs et al., 2018) \\
\hline El-Khalil, Raed & $\begin{array}{c}\text { Simulation analysis for managing } \\
\text { and improving productivity: A } \\
\text { case study of an automotive } \\
\text { company }\end{array}$ & 2015 & 6 & (El-Khalil, 2015) \\
\hline $\begin{array}{l}\text { Chahid, Mohamed Tarek } \\
\text { El Alami, Nouredine } \\
\text { Soulhi, Aziz } \\
\text { El Alami, Jamila }\end{array}$ & $\begin{array}{l}\text { Performance measurement model } \\
\text { for Moroccan automotive } \\
\text { suppliers: The MCDM approach } \\
\text { with AHP and nonadditive fuzzy } \\
\text { Sugeno integral }\end{array}$ & 2014 & 0 & (Chahid, N. El Alami, et al., 2014) \\
\hline $\begin{array}{c}\text { Dörnhöfer, Martin } \\
\text { Schröder, Falk } \\
\text { Günthner, Willibald A. }\end{array}$ & $\begin{array}{l}\text { Logistics performance } \\
\text { measurement system for the } \\
\text { automotive industry }\end{array}$ & 2016 & 5 & $\begin{array}{c}\text { (Dörnhöfer, Schröder and Günthner, } \\
\text { 2016) }\end{array}$ \\
\hline Charan, Parikshit & $\begin{array}{l}\text { Supply chain performance issues } \\
\text { in an automobile company: a SAP- } \\
\text { LAP analysis }\end{array}$ & 2012 & 18 & (Charan, 2012) \\
\hline $\begin{array}{l}\text { Chahid, Mohamed Tarek } \\
\text { El Alami, Jamila } \\
\text { Soulhi, Aziz } \\
\text { El Alami, Nouredine }\end{array}$ & $\begin{array}{l}\text { Performance measurement model } \\
\text { for Moroccan automotive } \\
\text { suppliers using PMQ and AHP }\end{array}$ & 2014 & 3 & (Chahid, J. El Alami, et al., 2014) \\
\hline $\begin{array}{l}\text { Behrouzi, Farzad } \\
\text { Wong, Kuan Yew }\end{array}$ & $\begin{array}{l}\text { An investigation and identification } \\
\text { of lean supply chain performance } \\
\text { measures in the automotive SMEs }\end{array}$ & 2011 & 20 & (Behrouzi and Wong, 2011) \\
\hline $\begin{array}{l}\text { Marodin, Giuliano Almeida } \\
\text { Frank, Alejandro Germán } \\
\text { Tortorella, Guilherme Luz } \\
\text { Saurin, Tarcisio Abreu }\end{array}$ & $\begin{array}{l}\text { Contextual factors and lean } \\
\text { production implementation in the } \\
\text { Brazilian automotive supply chain }\end{array}$ & 2016 & 15 & (Marodin et al., 2016) \\
\hline $\begin{array}{c}\text { Vaz, Caroline Rodrigues } \\
\text { Shoeninger Rauen, Tania } \\
\text { Regina } \\
\text { Rojas Lezana, álvaro } \\
\text { Guillermo }\end{array}$ & $\begin{array}{l}\text { Sustainability and innovation in } \\
\text { the automotive sector: A } \\
\text { structured content analysis }\end{array}$ & 2017 & 4 & $\begin{array}{c}\text { (Vaz, Shoeninger Rauen and Rojas } \\
\text { Lezana, 2017) }\end{array}$ \\
\hline $\begin{array}{l}\text { Dörnhöfer, Martin } \\
\text { Günthner, Willibald A. }\end{array}$ & $\begin{array}{c}\text { A research and industry } \\
\text { perspective on automotive } \\
\text { logistics performance } \\
\text { measurement }\end{array}$ & 2017 & 0 & (Dörnhöfer and Günthner, 2017) \\
\hline $\begin{array}{l}\text { Salleh, Noor Azlina Mohd. } \\
\text { Kasolang, Salmiah } \\
\text { Jaafar, Hj Ahmed }\end{array}$ & $\begin{array}{l}\text { Review study of developing an } \\
\text { integrated TQM with LM } \\
\text { framework model in Malaysian } \\
\text { automotive industry }\end{array}$ & 2012 & 20 & (Salleh, Kasolang and Jaafar, 2012) \\
\hline $\begin{array}{l}\text { Petrillo, Antonella } \\
\text { Felice, Fabio De } \\
\text { Zomparelli, Federico }\end{array}$ & $\begin{array}{l}\text { Performance measurement for } \\
\text { world-class manufacturing: a } \\
\text { model for the Italian automotive } \\
\text { industry }\end{array}$ & 2018 & 1 & (Petrillo, Felice and Zomparelli, 2018) \\
\hline $\begin{array}{l}\text { Fadly Habidin, Nurul } \\
\text { Mohd Fuzi, Nursyazwani }\end{array}$ & $\begin{array}{l}\text { Sustainable Performance Measures } \\
\text { for Malaysian Automotive } \\
\text { Industry }\end{array}$ & 2015 & 2 & (Fadly Habidin and Mohd Fuzi, 2015) \\
\hline
\end{tabular}




\section{Appendix B}

Table A2

Journal statistics

\begin{tabular}{|c|c|c|}
\hline Journal & $\begin{array}{l}\text { Impact } \\
\text { Factor }\end{array}$ & SJR 2017 \\
\hline Journal of Cleaner Production & 5.651 & 1.467 \\
\hline International Journal of Production Economics & 4.407 & 2.401 \\
\hline Supply Chain Management: An International Journal & 3.833 & 1.986 \\
\hline Expert Systems with Applications & 3.768 & 1.271 \\
\hline $\begin{array}{c}\text { International Journal of Operations and Production } \\
\text { Management }\end{array}$ & 2.955 & 2.052 \\
\hline Computers in Industry & 2.850 & 1.028 \\
\hline International Journal of Production Research & 2.623 & 1.432 \\
\hline Journal of Enterprise Information Management & 2.482 & 0.827 \\
\hline Journal of Manufacturing Technology Management & 2.194 & 0.867 \\
\hline Sustainability (Switzerland) & 2.075 & 0.537 \\
\hline International Journal of Logistics Management & 1.776 & 0.710 \\
\hline Total Quality Management \& Business Excellence & 1.526 & 0.634 \\
\hline Engineering Management Journal & 0.487 & 0.247 \\
\hline Benchmarking: An International Journal & - & 0.559 \\
\hline Gestao e Producao & - & 0.156 \\
\hline International Journal of Economics and Management & - & 0.322 \\
\hline $\begin{array}{c}\text { International Journal of Automotive Technology and } \\
\text { Management }\end{array}$ & - & 0.374 \\
\hline International Journal of Emerging Markets & - & 0.474 \\
\hline $\begin{array}{c}\text { International Journal of Fashion Design, Technology and } \\
\text { Education }\end{array}$ & - & 0.180 \\
\hline International Journal of Logistics Systems and Management & - & 0.371 \\
\hline $\begin{array}{c}\text { International Journal of Productivity and Performance } \\
\text { Management }\end{array}$ & - & 0.578 \\
\hline International Journal of Quality \& Reliability Management & - & 0.492 \\
\hline International Journal of Value Chain Management & - & 0.116 \\
\hline Journal of Theoretical and Applied Information Technology & - & 0.161 \\
\hline Logistics Research & - & 0.702 \\
\hline Measuring Business Excellence & - & 0.373 \\
\hline Modern Applied Science & - & 0.188 \\
\hline Scientific Research and Essays & - & 0.170 \\
\hline The TQM Journal & - & 0.451 \\
\hline World Applied Sciences Journal & - & 0.156 \\
\hline
\end{tabular}


(C) 2019 by the authors; licensee Growing Science, Canada. This is an open access article distributed under the terms and conditions of the Creative Commons Attribution (CC-BY) license (http://creativecommons.org/licenses/by/4.0/). 